\title{
COMPARATIVE STUDY OF BACTERIOLOGICAL PATTERN \& DRUG RESISTANCE IN ASOM \& CSOM
}

Rakesh Kumar $^{1}$

\section{HOW TO CITE THIS ARTICLE:}

Rakesh Kumar. "Comparative study of bacteriological pattern \& drug resistance in ASOM \& CSOM". Journal of Evolution of Medical and Dental Sciences 2013; Vol2, Issue 37, September 16; Page: 7138-7147.

ABSTRACT: AIMS \& OBJECTIVE: Comparative study of bacteriological pattern of ASOM \& CSOM \& their drug sensitivity pattern. MATERIAL \& METHODS: Aural pus swab (after taking all aseptic precautions) was taken from patients having clinical signs and symptoms of ASOM \& CSOM \& sent for culture (aerobic\& anaerobic) \& drugs sensitivity pattern to laboratory. RESULT: In the present study we have found In ASOM, streptococcus pneumoniae is found in $31.2 \%$, staphylococcus $27 \%$, E coli $18 \%$, and sterile $18 \%$ of cases. In CSOM, staphylococcus is found in $37 \%$, pseudomonas $24 \%$, E coli $14 \%$, streptococcus $12 \%$. of cases. Among all drugs studied - Cephalosporins, Amikacin \& Norfloxacin are found more sensitive. In majority of cases multi drug resistance is found. In patients with cholesteatoma, staphylococcus aureus \& pseudomonas was found. CONCLUSION: Present observation indicates that: In ASOM cases, Streptococcus pneumoniae is found as most common bacteria followed by staphylococcus aureus and E coli. In CSOM cases staphylococcus aureus is found most common pathogen followed by pseudomonas. Among all studied drugs, Amikacin, Gentamicin, Norfloxacin \& Cephalosporins (gen III \& IV) were found most effective.

Key Words: ASOM, CSOM, streptococcus pneumonia, staphylococcus aureus, Multi drug resistance.

Introduction: Otitis Media is a multifactorial disease involving microbiological organisms, environmental risk factors \& host characteristics. (Chandrasekhar MR, Krishna BVS 2004). Ref (1) $\mathrm{OM}$ is defined as an inflammation of the middle ear cleft without reference(specific) etiology and pathogenesis the middle ear cleft consist of the tympanic cavity (tympanum), the Eustachian tube and the mastoid air all system.

\section{Otitis media can be classified as}

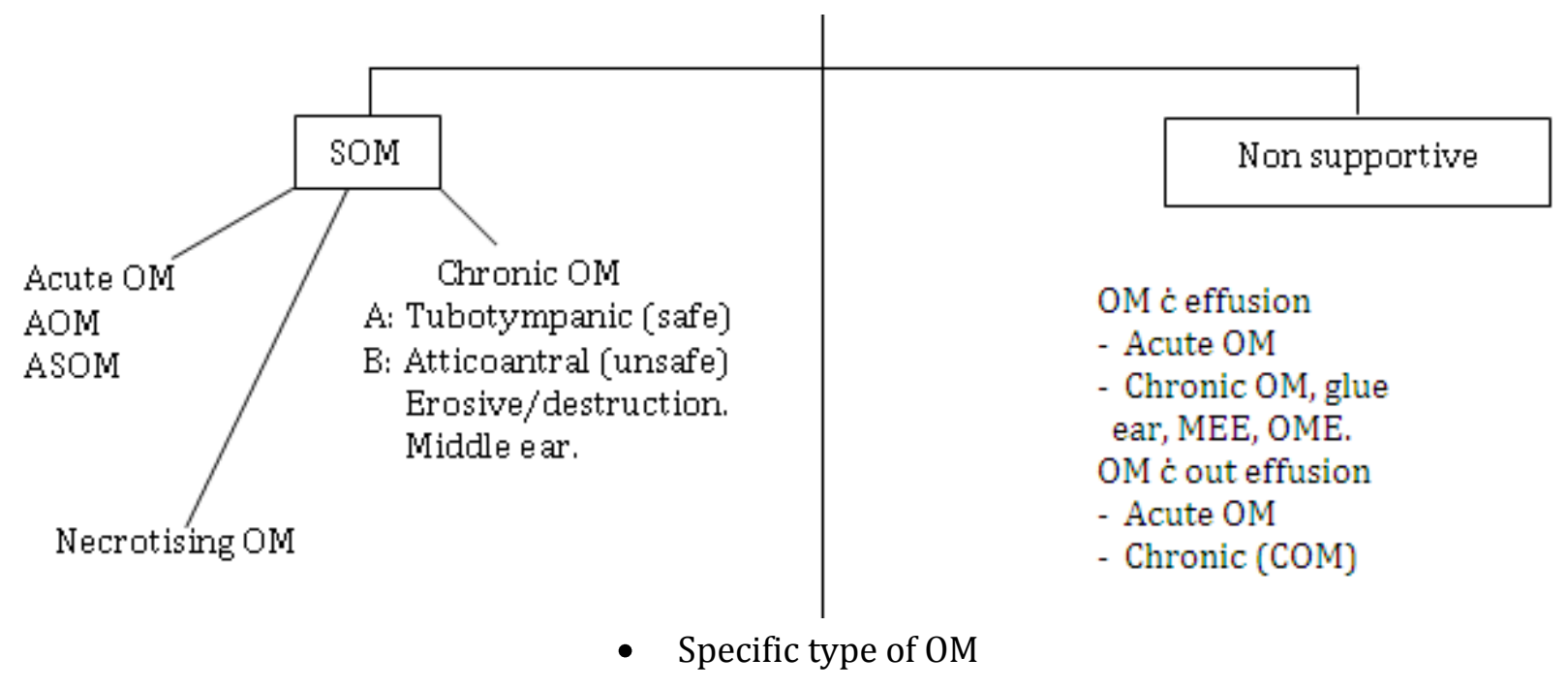

Journal of Evolution of Medical and Dental Sciences/ Volume 2/ Issue 37 / September 16, 2013

Page 7138 


\section{ORIGINAL ARTICLE}

- Tubercular OM

- Syphilitic OM

Hippocrates: Acute pain of the ear with continued strong fever is to be dreaded, for there is danger that man becomes delirious and die. The term suppurative otitis media means a purulent inflammation of the middle ear cleft. It implies the presence of pus and in its original use indicated that the ear was making or discharging pus. The cause is often purely infective but other agents such as allergy, cholesteatoma, chemical irritants, auto-immune disease and others may underlie the discharge.

It is necessary to establish as to whether it is viral or bacterial in nature viral AOM is usually a consequence of upper respiratory virus i.e. rhinovirus, respiratory Syncytial virus which present as congestion and middle ear fluid accumulation.

Fluid may persist even for months leading to deafness. While bacterial infection present with Signs and symptoms of acute inflammation, pain in ear, congestion and bulging of tympanic membrane. White, yellow or turbid fluid behind it may be associated with malaise and mild pyrexia. Acute otitis media is usually a result of migration of nasopharyngeal bacterial flora into the middle ear through Eustachian tube.

Bacteriologically as well as etiologically both types are different due to prevalence of multiple pathogens. Because of indiscriminate use of antibiotic the bacteriological scenario has changed.

25 to $35 \%$ of children will have suffered one or more attacks before 7 years of age. Abnormal function of the Eustachian tube appears to be the most important factors in the pathogenesis of the middle ear disease.

Some recent studies show the predominant involvement of one side than bilateral involvement.

Majority of patients complains of discharge from either from a Single ear or both ears. Pain is the next common symptom followed by ear-itching, loss of hearing and tinnitus. In the present study, an attempt is made to study the incidence of otitis media and their anti microbial sensitivity pattern for anti microbial agents.

METHODS: The present study is carried out at department of ENT, Netaji Subhash Chandra Bose, Medical College \& Hospital, Jabalpur from July 2004 to June 2005 and involve 100 patient attending ENT outpatient department of age of 3-14 year of age presented with clinical symptoms \& signs of otitis media. Patients with otitis externa and referred otalgia were excluded.

The ear showing the discharge were thoroughly cleaned externally with saline \& disinfected with spirit before taking swab from the meatus. Aural swab were then sent to pathology test. Other investigation like X-ray mastoid oblique view, CBP ESR urine examination \& Pure Tone Audiometry were also carried out.

RESULT: Males are more affected then female (1.32:1).Ear discharge (Rt $>$ Lt) followed by hearing impairment were the most common presenting complaint. 


\section{ORIGINAL ARTICLE}

In ASOM streptococcus is the most common causative organism cultured followed by staphylococcus and E coli. Most of the patient present with mild \& moderate conductive hearing loss and most of patient have pneumatized mastoid.

In CSOM staphylococcus aureus \& pseudomonas are most common \& most of patients present with moderate conductive hearing loss \& most of patient have sclerosed mastoid.

Most of pathogenic organism develops multi resistance against antimicrobial drugs.

Amikacin, Gentamycin, cephalosporin group III \& IV \& ciprofloxacin were the most effective drugs.

DISCUSSION: The present study includes 100 cases of OM in one year duration.

Out of 100 studies cases $57 \%$ were male and $41 \%$ were female giving a male: female ratio of 1.32:1. This shows that males were more affected than female *as found by Vijaya D $(62.77 \% \mathrm{M})$ 1998, Parveen Naheed (62.03\%) 2002, Gulati et al (61\% M) 1997.Ref $(11,8,21)$ (Table No. I). In the present study majority of patients (65\%) were from poor socioeconomic group (31\%) from middle socioeconomic group and (4\%) were from upper socioeconomic group Gulati 1997. Ref (21) ASOM was found in 23 cases (4Lt 19Rt) *as found by Lalwani \& Scoy (1992), Robbins Schneerson \& Szu (1988) De Moria et al (1984). Ref (10, 2, 5, 6) (Table No. II \& III) CSOM was found in 78 cases (47 safe, 31 unsafe) 22Left and 31Right sided.

In our study ear discharge was the most common presenting symptoms (in $\geq 95 \%$ ), hearing loss (61\%), cough \& cold* as found by Rao BN, Reddy MS (1991), Gulati et al (1997) Reddy Venugopal (1998). Ref (24,16,21) (Table No. IV). In 37\% cases of CSOM - staph aureus, 24\% pseudomonas, * as found by Chandra shekhar 2004, Vijaya Das (2000) Alanazi et al (1998). Ref (1,11, 14) In ASOM 70\% - streptococcus pneumonia, 27\% - staph aureus as found by Nwawolo cc 2001, Maruyama J 1996. (Table No.V). In patient having cholesteatoma - 46\% have shown staphylococcus aurous *as found by Gupta Vinita et al (1998), Rao BN \& Reddy 1994, Karma P 1998.Ref(18,24,40) $30.8 \%$ - pseudomonas, $77 \%$ proteus \& streptococcus in $7 \%$ agent. (Table No. VI).

Present study show that most of bacteria show resistance to 3 or more antimicrobial agent. Cephalosporin group of drugs are least resistant group \& effective against most bacteria cultured from aural swab *as found by Brook I 2004, Go K U Bulut Y 2001, Nyembwe DT Alanazi et al 1998, Vijaya D 2000 Varshenoy et al 1999 Ref $(33,14)$ followed by Amikacin, Gentamycin and Ciprofloxacin. Most of cultured organisms shows (Parveen Naheed 2000) Ref (8) resistance against ampicillin clindamycin amoxicillin and norfloxacin group of drug. (Table No. VII \& VIII).

Statistical cross-relation of bacteriological study of aural discharge with throat swab was done to check the control of study results. (Table No. IX).

In the study of 78 cases of CSOM child ofloxacin was susceptible on all pathogenic bacteria \& neomycin 96\% and Gentamycin 83\%susceptibility was found *as found by Vijaya D (2000), Varshenoy et al (1999)Ref(11)

Most of pathogen were resistant to amoxicillin*as found by Parveen Naheed (2000) Ref(8).

The results of present study are in well accordance with various authors in previous studies. (Table No. X). 
CONCLUSION: Present observation indicates that:

In ASOM cases, Streptococcus pneumoniae is found as most common bacteria followed by staphylococcus aureus and E coli.

In CSOM cases staphylococcus aureus is found most common pathogen followed by pseudomonas.

Among all studied drugs, Amikacin, Gentamicin, Norfloxacin \& Cephalosporins (gen III \& IV) were found most effective.

\begin{tabular}{|c|c|c|c|}
\hline Age (in years) & $\begin{array}{l}\text { Male } \\
(\%)\end{array}$ & $\begin{array}{c}\text { Female } \\
(\%)\end{array}$ & Total \\
\hline $0-3$ & $\begin{array}{c}6 \\
(10.5)\end{array}$ & $\begin{array}{c}1 \\
(2.3)\end{array}$ & $\begin{array}{c}7 \\
(7.0)\end{array}$ \\
\hline $3-6$ & $\begin{array}{c}7 \\
(12.3) \\
\end{array}$ & $\begin{array}{c}8 \\
(18.6) \\
\end{array}$ & $\begin{array}{c}18 \\
(15.0)\end{array}$ \\
\hline $6-9$ & $\begin{array}{c}10 \\
(17.5)\end{array}$ & $\begin{array}{c}10 \\
(23.3)\end{array}$ & $\begin{array}{c}20 \\
(20.0)\end{array}$ \\
\hline $9-12$ & $\begin{array}{c}26 \\
(45.6)\end{array}$ & $\begin{array}{c}16 \\
(37.2)\end{array}$ & $\begin{array}{c}42 \\
(42.0)\end{array}$ \\
\hline $12-14$ & $\begin{array}{c}8 \\
(14.0)\end{array}$ & $\begin{array}{c}8 \\
(18.6)\end{array}$ & $\begin{array}{c}16 \\
(16.0)\end{array}$ \\
\hline Total & 57 & 43 & 100 \\
\hline $\begin{array}{l}\text { Mean } \\
\pm \text { SD }\end{array}$ & $\begin{array}{c}9.16 \\
\pm 3.36\end{array}$ & $\begin{array}{c}9.56 \\
\pm 3.24\end{array}$ & $\begin{array}{c}9.33 \\
\pm 3.30\end{array}$ \\
\hline \multicolumn{4}{|c|}{$Z=0.60 ; P>0.05$} \\
\hline
\end{tabular}

Table 1: Age and sex wise distribution of the studied cases

\begin{tabular}{|l|c|c|}
\hline \multicolumn{1}{|c|}{ Symptoms } & No of Cases & Percentage \\
\hline Discharge & 95 & 95 \\
\hline Hearing loss & 56 & 56 \\
\hline Cough \& Cold & 43 & 43 \\
\hline Ear ache & 8 & 8 \\
\hline Tinnitus & 8 & 8 \\
\hline Ear fullness & 5 & 5 \\
\hline Headache & 3 & 3 \\
\hline Vertigo & 1 & 1 \\
\hline Fever & 1 & 1 \\
\hline
\end{tabular}

Table 2: Study of presenting symptoms of otitis media 
ORIGINAL ARTICLE

\begin{tabular}{|c|c|c|c|}
\hline & Frequency & Percentage & Total \% \\
\hline AOM (Rt.) & 4 & 4.0 & 4 \\
\hline ASOM (Lt.) & 4 & 4.0 & \multirow{4}{*}{19} \\
\hline ASOM (Rt.) & 9 & 9.0 & \\
\hline ASOM (Rt.) + AOM (Lt.) & 1 & 1.0 & \\
\hline ASOM B/L & 5 & 5.0 & \\
\hline CSOM (B/L) Safe & 22 & 22.0 & \multirow{3}{*}{46} \\
\hline CSOM (Rt.) Safe & 13 & 13.0 & \\
\hline CSOM Safe (Lt.) & 11 & 11.0 & \\
\hline CSOM Unsafe (Rt.) & 18 & 18.0 & \multirow{3}{*}{31} \\
\hline CSOM (B/L) Unsafe & 2 & 2.0 & \\
\hline CSOM (Lt.) Unsafe & 11 & 11.0 & \\
\hline Total & 100 & 100.0 & \\
\hline
\end{tabular}

Table 3: Incidence of various types of otitis media in co-relation on with laterality

\begin{tabular}{|l|c|c|}
\hline \multicolumn{1}{|c|}{ Symptoms } & No of Cases & Percentage \\
\hline Discharge & 95 & 95 \\
\hline Hearing loss & 56 & 56 \\
\hline Cough \& Cold & 43 & 43 \\
\hline Ear ache & 8 & 8 \\
\hline Tinnitus & 8 & 8 \\
\hline Earfullness & 5 & 5 \\
\hline Headache & 3 & 3 \\
\hline Vertigo & 1 & 1 \\
\hline Fever & 1 & 1 \\
\hline
\end{tabular}

Table 4: Study of presenting symptoms of otitis media 


\section{ORIGINAL ARTICLE}

\begin{tabular}{|l|c|c|c|c|}
\hline \multicolumn{1}{|c|}{ Bacteria } & ASOM & CSOM & Total Frequency & Percent \\
\hline Proteus & 0 & 3 & 3 & 3.0 \\
\hline Aspergillus & 1 & 2 & 3 & 3.0 \\
\hline E. Coli & 4 & 11 & 15 & 15.0 \\
\hline Klebsiella & 0 & 1 & 1 & 1.0 \\
\hline Pseudo & 0 & 19 & 19 & 19.0 \\
\hline Staph. Aureus & 6 & 29 & 35 & 35.0 \\
\hline Sterile & 4 & 4 & 8 & 8.0 \\
\hline Strepto P & 7 & 9 & 16 & 16.0 \\
\hline \multicolumn{1}{|c|}{ Total } & $\mathbf{2 2}$ & $\mathbf{7 8}$ & $\mathbf{1 0 0}$ & $\mathbf{1 0 0 . 0}$ \\
\hline
\end{tabular}

Table 5: Bacteriological study of Aural swab in studied cases

\begin{tabular}{|c|c|c|c|}
\hline \multirow{2}{*}{ Aural swab Culture } & \multicolumn{2}{|c|}{ CHOLESTEATOMA } & \multirow[t]{2}{*}{ Total } \\
\hline & Present & Absent & \\
\hline \multirow{2}{*}{ B Proteus } & 1 & 2 & 3 \\
\hline & $7.7 \%$ & $2.3 \%$ & $3.0 \%$ \\
\hline \multirow{2}{*}{ E. Coli } & 1 & 14 & 15 \\
\hline & $7.7 \%$ & $16.1 \%$ & $15.0 \%$ \\
\hline \multirow{2}{*}{ Klebsiella } & 0 & 1 & 1 \\
\hline & $.0 \%$ & $1.1 \%$ & $1.0 \%$ \\
\hline \multirow{2}{*}{ Pseudomonas } & 4 & 15 & 19 \\
\hline & $30.8 \%$ & $17.2 \%$ & $19.0 \%$ \\
\hline \multirow{2}{*}{ Staph. Aureus } & 6 & 29 & 35 \\
\hline & $46.2 \%$ & $33.3 \%$ & 35.0 \\
\hline \multirow{2}{*}{ Streptococcus Pneumoniae } & 1 & 15 & 16 \\
\hline & $7.7 \%$ & $17.2 \%$ & $16.0 \%$ \\
\hline \multirow{2}{*}{ Sterile } & 0 & 11 & 11 \\
\hline & $.0 \%$ & $12.6 \%$ & $11.0 \%$ \\
\hline Total & 13 & 87 & 100 \\
\hline
\end{tabular}

Table 6: Study of Aural swab Culture in cholesteatoma positive cases 


\section{ORIGINAL ARTICLE}

\begin{tabular}{|c|c|c|c|c|c|c|c|c|c|c|}
\hline Bacteria & 莺 & 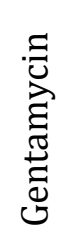 & 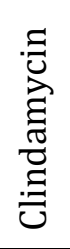 & 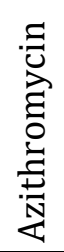 & 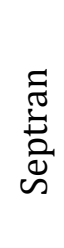 & 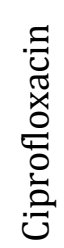 & 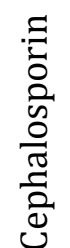 & 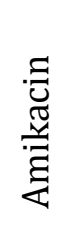 & 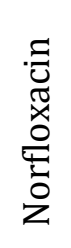 & 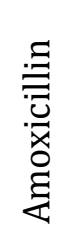 \\
\hline Strepto P & 11 & 13 & 10 & 14 & 12 & 12 & 12 & 16 & 8 & 13 \\
\hline Staph A & 14 & 25 & 28 & 29 & 26 & 28 & 34 & 32 & 15 & 09 \\
\hline Pseudo & 4 & 10 & 8 & 11 & 5 & 14 & 18 & 17 & 8 & 11 \\
\hline Klebsiella & 0 & 1 & 1 & 1 & 1 & 1 & 1 & 1 & 1 & 1 \\
\hline Proteus & 3 & 2 & 1 & 1 & 2 & 3 & 3 & 3 & 2 & 1 \\
\hline E coli & 11 & 7 & 8 & 8 & 9 & 11 & 15 & 15 & 11 & 10 \\
\hline Total & 43 & 58 & 56 & 64 & 55 & 69 & 83 & 84 & 45 & 45 \\
\hline
\end{tabular}

Table 7: Antibiotics sensitivity pattern of the bacteria isolated from aural discharge of ASOM cases

\begin{tabular}{|c|c|c|c|c|c|c|c|c|c|c|}
\hline Bact & 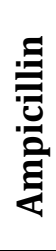 & 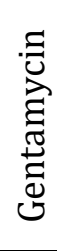 & 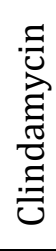 & 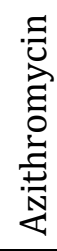 & 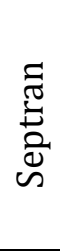 & 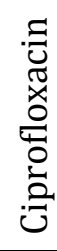 & 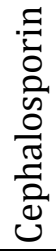 & 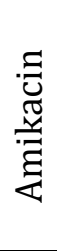 & 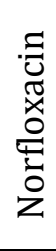 & 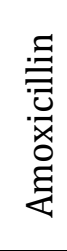 \\
\hline Strepto P & 6 & 8 & 6 & 7 & 6 & 6 & 8 & 9 & 5 & 6 \\
\hline Staph A & 13 & 18 & 23 & 24 & 22 & 22 & 28 & 26 & 14 & 18 \\
\hline Pseudo & 4 & 11 & 8 & 12 & 6 & 15 & 18 & 17 & 10 & 4 \\
\hline Klebsiella & 1 & 1 & 1 & 1 & 1 & 1 & 1 & 1 & 1 & 1 \\
\hline Proteus & 3 & 2 & 1 & 1 & 2 & 3 & 3 & 3 & 2 & 1 \\
\hline E coli & 8 & $J$ & 6 & 5 & ' & 8 & 11 & 11 & 8 & 8 \\
\hline Total & 35 & 45 & 45 & 50 & 44 & 55 & 69 & 67 & 40 & 38 \\
\hline
\end{tabular}

Table 8: Antibiotics sensitivity pattern of the bacteria isolated from aural discharge of CSOM cases

\begin{tabular}{|c|c|c|c|c|}
\hline & & \multicolumn{2}{|c|}{ Throat swab } & Total \\
\hline & & Positive & Negative & \\
\hline Aural swab & Positive & 60 & 89 & 149 \\
\hline & Negative & 40 & 11 & 51 \\
\hline & Total & 100 & 100 & 200 \\
\hline Mean \pm SD $=$ & & $\mathbf{9 . 1 6} \pm \mathbf{3 . 3 6}$ & $\mathbf{9 . 5 6} \pm \mathbf{3 . 2 4}$ & $\mathbf{9 . 3 3} \pm \mathbf{3 . 3 0}$ \\
\hline \multicolumn{5}{r}{$\mathrm{X}^{2}=22.13 ; \mathrm{P}<0.0001$} \\
\hline
\end{tabular}

Table 9: Statistical cross-relation of bacteriological study of Aural discharge with throat swab 


\section{ORIGINAL ARTICLE}

\begin{tabular}{|c|c|c|c|c|c|c|c|c|c|}
\hline & $\begin{array}{c}\text { Present } \\
\text { study }\end{array}$ & $\begin{array}{c}\text { Vijaya } \\
\mathrm{D} \\
2000\end{array}$ & $\begin{array}{c}\text { Parveen } \\
\text { Naheed } \\
2002\end{array}$ & $\begin{array}{c}\text { Rao \& } \\
\text { Reddy } \\
1994\end{array}$ & $\begin{array}{c}\text { Gulati } \\
1997\end{array}$ & $\begin{array}{c}\text { Al. } \\
\text { Anazi } \\
\text { et al } \\
1998\end{array}$ & $\begin{array}{c}\text { Nagarat } \\
\text { Hnammat } \\
1998\end{array}$ & $\begin{array}{c}\text { Chandra } \\
\text { shekhar } \\
2004\end{array}$ & $\begin{array}{c}\text { Ibekwe } \\
\text { Ao et al. } \\
1983\end{array}$ \\
\cline { 2 - 11 } St. pn. & 16 & 3 & 26 & 5.83 & & & & $\%$ & $\%$ \\
\hline Staph A & 35 & 36.23 & 10 & 42.50 & 16.6 & 25.71 & 19.90 & 17.98 & 20.7 \\
\hline Pseudo & 19 & 19.72 & 15 & 21.60 & 41 & 25.71 & 7.28 & 46.76 & 22.5 \\
\hline E. Coli & 15 & 0.91 & 4.2 & 10.83 & 15.6 & & & & \\
\hline Kleb. & 1 & 10.55 & 3 & 10 & 16 & 2.35 & 18.44 & 12.23 & 2.7 \\
\hline Aspergi & 3 & & & 7.5 & 10 & 17.14 & 10.19 & & 17.1 \\
\hline Proteus & 3 & 6.41 & 4 & 18 & 5.6 & 5.88 & 3.88 & & 3.6 \\
\hline
\end{tabular}

\section{BIBLIOGRAPHY:}

1. Chandrasekhar MR, Krishna BVS : A bacteriological profile of CSOM. Indian Jr. of Otology Vol. 10, Dec. 2004. P. 10-13.

2. Polachek A, Greenberg D. : Etiologic agents and clinical manifestation in acute otitis media. Pediatric infectious disease journal 2004 may; 23 (5): 406.

3. Graces- Sanchez M, Diez- Domingo J.: Epidemiology and burden of acute O.M. in Valencia's (Spain). An paediatic (Bare) 2004 Feb; 600 (2): 125-32.

4. Marchisio P, Claut L. Differences in nasopharyngeal bacterial flora in children with nonsevere recurrent acute otitis media and chronic otitis media. Pediatic infect Dis. J 2003 March; 22 (3): 262-8.

5. Diagnosis and management of acute otitis media. Am. Academy of Paediatrics. J. Vol. 113 no. 5: May 2004.

6. Otitis media with effusion. American Academy of Peadiatrics J. Vol 113, No. 3 May 2004.

7. Moriniere S, Lanotte P. : Acute mastoiditis in children, Press Med 2003 Sep. 27;32 (31) : 1445- 9.

8. Perwin Naheed, Khan Zulfia : Bacteriological study of OM- A rural study. Indian J. of Otology Vol. 9. Dec. 2002. P. 29-32.

9. Blue stone CD, Gates GA, Klin JO et al: Panel Reports definition, terminology and classification of otitis media. Ann atol Rhinol laryngeal 2002, III suppl. 188:8-18.

10. Nwawolo CC, Odeusanya 00: Clinical profile of acute otitis media among Nigerian children. West African Journal of Medicine. 20(3)"187-90, 2001 July - Sept.

11. Vijaya D, Aerobes : Anaerobes and Fungi in CSOM. Indian Jr. of Otology Vol. 6 No. 3 (Sept. 2000): 55-58.

12. Contributing factors in otitis media. India Jr. of Otology Vol. 5 No. 3 (Sept 98), 111-114. 


\section{ORIGINAL ARTICLE}

13. Vijaya D. Nagarathnamma T. Microbiological study of CSOM. Indian Jr. of Otology. Vol. 4 No. 4(Dec. 98), 172-174.

14. Alanazy Fatma, Saad Assiry: Microbiology evaluation and aspects on management of CSOM in Riyadh. Indian Jr. of Otology Vol 4, No. 3 (Sept. 98), 115-120.

15. Arguedas A, Loaiza C, Microbiology of acute of otitis media in costa Rican children. Pediatric infections disease Journal 1998 Aug; 17(8) 680-9.

16. Reddy, Venu Gopal: Secretory otitis media. Indian Jr. of otology Vol. 4 (4) (Dec. 98) 157-160.

17. Taneja MK: Acute otitis media. Indian Jr. of Otology Vol. 4 (4) (Dec. 1998): 161-164.

18. Gupta Vineeta, Gupta Abhay : CSOM microbiological study. Indian Jr. of Otology. Vol. 4, No. 2 (June 1998); 79-82.

19. Okeke EN, Juret Z: West African Jr of Medicine 14 (4):238-41; 1998.

20. Le. Bideau M, Mouzard A, Bacteriological study of Acute OM. Archives de pediatric 4 (3) : 213-8, 1997 March.

21. Gulati, Sudesh Kumar: Investigative profile in patients of CSOM. Indian Jr. of Otology Vol. 3, No. 2;1997, 59-62.

22. Vartiainen E, Vartiainen J: Effect of aerobic bacteriology on the Clinical Presentation and treatment of CSOM. Journal of laryngology and otology. 110(4); 315-8, 1996.

23. Maruyama J. Aritoma H: Clinical Studies on acute OM in infant. Jr. of

24. Rao BN, Reddy MS: CSOM A prospective study. Indian Jr. of Otology Vol 3 (2); 72-77:1994.

25. Feans LV and Blood IM : The behavioural and language sequelae of otitis media in infants and young children attending day care in : recent advance in otitis media, edited by D.J. Lim, tarontoz BC dacker. P. 521-523, 1993.

26. Claessen et al: A review of clinical trials regarding treatment of acute of acute otitis media. Clinical otolaryngology. 17, 1992:251-57.

27. Ovesen T And Blegvad-Anderson 0 : Alteration in tympanic membrane appearance of middle ear function in 11 years old children with complete unilateral cleft lip and palate. Clinical otolaryngol otology 17, 2031992.

28. Froom J, Clupepper L: Otitis media in children in day care centers. Journal of family practice. 32, $289-294,1891$.

29. Black et al: A randomized controlled trial of surgery for glue ear. British Medical Journal. 300, 1551-1556:1990.

30. Gehanno P, Boucot I : Bacterial epidemiology of acute OM Annales de pediatric (Paris) 39, 485-490 1990.

31. Luntz M and Sade J : Growth of the ET lumen with age. American Journal of otolaryngology. 9, 195-198: 1988.

32. Kero P \& Piek Kakla P: Factors affecting the occurrence of acute otitis media during the first year of life. Acute Padiatrica Scandinavica. 76; 618-623:1987.

33. Brook I.: Prevalence of beta-lactamase producing bacteria in CSOM. American Jr. of Diseases of children. 139; 280-83: 1985.

34. Karma et al: Middle ear fluid bacteriology of acute otitis media in neonates and very young adults. International Journal of Paediatric otorhino laryngology. 14;141-1150:1987.

35. Ammann AZ, Shannon K : Recognition of AIDS in children. Pediatr. Rev. 7; 101-7:1985. 


\section{ORIGINAL ARTICLE}

36. Sade J: The infants Eustachian tube lumen pharyngeal part. Jr. of laryngology and otology. $100 ; 129-134: 1985$.

37. Teele DW, Klein ZO: OM with effusion pediatrics. 74; 281-7:1984.

38. Tos M: Upon the relationship between secretary otitis in childhood and chronic otitis and its sequelae in adults. Jr. of Laryngology and Otology: 9; 456-464:1981.

39. Palva A, Karma P: Cholesteatoma in children archives of otolaryngology. 103; 74-77:1977.

40. Karma et al: Bacteriology of the chronically discharging middle ear. Acta otolaryngologica. 86; 110-114:1978.

41. Senturia BH: Studies concerned with tubo-tympanitis. Ann atol Thinol Laryngol. 67; 44067:1958.

42. Anatomy and ultra structure of the human ear. Antony Wright; Scott Brown's Vol. $5^{\text {th }}$ Ed.

43. Hentzer E: Ultra structure of the lymphatic membrane. Acta otolaryngologica. 63; 376-390; 1969.

\section{AUTHORS:}

1. Rakesh Kumar

\section{PARTICULARS OF CONTRIBUTORS:}

1. Assistant Professor, Department of ENT, Chirayu Medical College and Hospital, Bairagarh, Bhopal.

\section{NAME ADDRESS EMAIL ID OF THE} CORRESPONDING AUTHOR:

Dr. Rakesh Kumar, S-556, Nehru Nagar, Bhadbhada Dam Road, Bhopal - 462003.

Email-drakes_raj@yahoo.co.in

Drakes.raj@gmail.com

Date of Submission: 31/07/2013.

Date of Peer Review: 04/09/2013.

Date of Acceptance: 11/09/2013.

Date of Publishing: 13/09/2013 